\title{
THE EVALUATION METOD OF TRANSPORT SYSTEM ON THE BASIS OF SEMI-MARKOV MODEL OF THE OPERATION AND MAINTENANCE PROCESS \\ METODA OCENY SYSTEMU TRANSPORTOWEGO NA PODSTAWIE SEMIMARKOWSKIEGO MODELU PROCESU EKSPLOATACJI
}

\author{
Maciej Woropay ${ }^{1)}$, Klaudiusz Migawa ${ }^{2)}$ \\ ${ }^{1)}$ Air Force Institute of Technology \\ ${ }^{2)}$ UTP University of Science and Technology \\ e-mail, klaudiusz.migawa@utp.edu.pl
}

\begin{abstract}
The article presents a method for assessment of availability and risk functioning of technical objects (transport means) in an executive subsystem. Indexes of the availability and risk connected with functioning of a single technical object have been determined on the basis of a mathematical model of the operation and maintenance process, in the studied transportation system. A Mathematical model of the operation and maintenance process has been developed with acceptance of an assumption that the process model is to be represented by a homogeneous Markov model X(t).
\end{abstract}

Keywords: transport, semi-Markov process, availability, risk

Streszczenie: $W$ artykule przedstawiono metodę oceny gotowości i ryzyka funkcjonowania obiektów technicznych (środków transportu) $w$ podsystemie wykonawczym systemu transportowego. Wskaźniki gotowości i ryzyka funkcjonowania pojedynczego obiektu technicznego zostały wyznaczone na podstawie matematycznego modelu procesu eksploatacji, realizowanego $w$ badanym systemie transportowym. Model matematyczny procesu eksploatacji zostat zbudowany przy przyjęciu założenia, że modelem tego procesu jest jednorodny proces Markowa X(t).

Slowa kluczowe: transport, proces semi-Markowa, gotowość, ryzyko 
The evaluation metod of transport system on the basis of semi-Markov model... Metoda oceny systemu transportowego na podstawie semimarkowskiego modelu...

\section{Introduction}

Transport system consists of two basic subsystems: executive subsystem and serviceability assurance subsystem. The executive subsystem is responsible for accomplishment of transport tasks and generation of profits from execution of these tasks. In the serviceability assurance subsystem, processes connected with maintaining transport means fit for operation are performer. Operation efficiency of a transport system depends on its possibility of proper execution of an assigned transport task. One of methods for assessment of the possibility of proper execution of a transport task is assessment operation risk and availability of the transport system.

The considered method presents a way of determination of indexes describing availability and risk connected with operation of a single technical object in the transport system executive subsystem. In the paper, values of availability and operation risk indexes for a single technical object are determined on the basis of the mathematical model of operation and maintenance process. Due to random character of factors affecting the course and efficiency of transport means operation and maintenance process, stochastic processes are most frequently used for mathematical modelling of the operation and maintenance process. Among random processes, semi-Markov's ones have found wide application for modeling the technical objects operation and maintenance process $[1,2,4,5,6,10]$. Application of semi-Markov's processes enables development and analysis of the mathematical model of the operation and maintenance process, in case when variables characterizing the process states are any distributions. Simulating tests with the use of the considered models of the operation and maintenance process make it possible to make a thorough analysis of problems connected with operation and maintenance of technical objects.

\section{Semi-Makovian model of operation and maintenance process of transport means}

The evaluation of the availability and risk of operation and maintenance system of transport means (technical objects) may be performed on the basis of Markovian or semi-Markovian model of the operation and maintenance process carried out in the tested system.

The paper presents the mathematical model of the analyzed transport means operation and maintenance process was built with the use of the semi-Markov processes theory. Due to the identification of the analyzed operation and maintenance process of transport means, crucial operation states of the process as well as possible transfers between the defined states were designated. Based on this, a graph was created, depicting the changes of operation and maintenance process states, shown in Figure 1. 


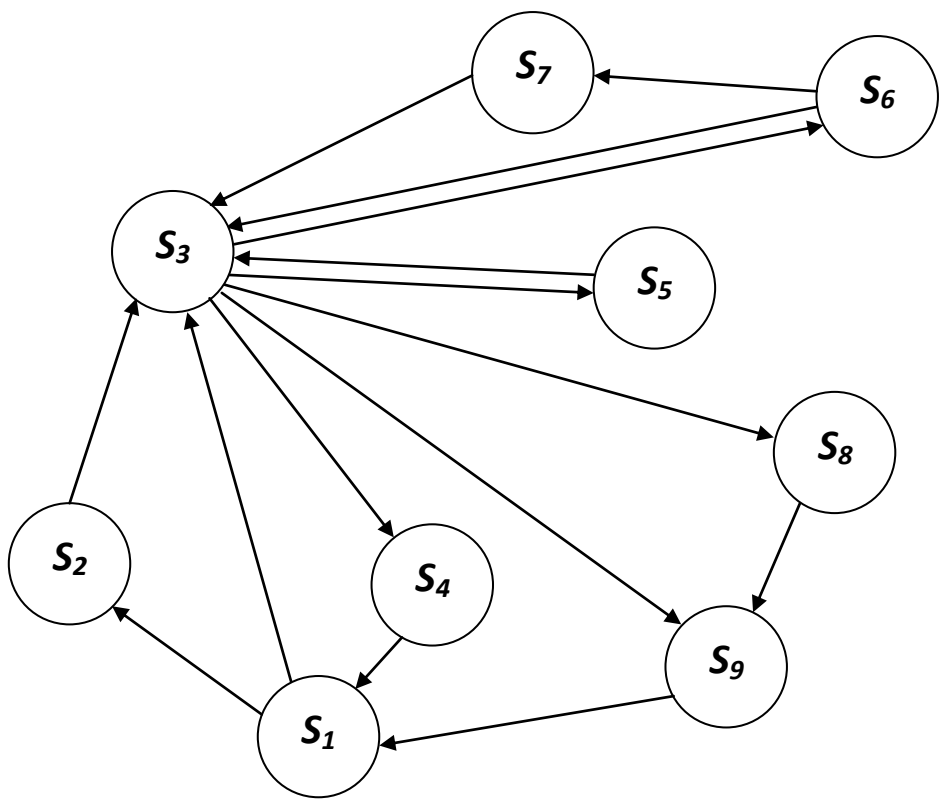

Fig. 1 Directed graph representing the transport means operation and maintenance process

$S_{1}$ - refueling, $S_{2}$ - awaiting the carrying out of the task at the bus depot parking space, $S_{3}$-carrying out of the transport task, $S_{4}$-awaiting the carrying out of the task between transport peak hours, $S_{5}$ - repair by the emergency service without losing a ride, $S_{6}$ - repair by the emergency service with losing a ride, $S_{7}$-awaiting the start of task realization after technical support repair, $S_{8}$ - repair in the serviceability assurance subsystem, $S_{9}$ - maintenance check on the operation day

The semi-Markov $X(t)$ process is one, where periods of time between the changes of consecutive process states have arbitrary probability distributions and a transfer to the consecutive state depends on the current process state. Using the semiMarkov processes in mathematical modelling of the operation and maintenance process, the following assumptions were put forward:

- the modelled operation and maintenance process has a finite number of states $S_{i}$, $i=1,2, \ldots, 9$,

- if technological object at moment $t$ is in state $S_{i}$, then $X(t)=i$,

- the random process $X(t)$ being the mathematical model of the operation and maintenance process is a homogenous process,

- at moment $t=0$, the process finds is in state $S_{3}$ (the initial state is state $S_{3}$ ), i.e. $P\{X(0)=3\}=1$.

The homogenous semi-Markov process is unequivocally defined when initial distribution and its kernel are given. Form our assumptions and based on the directed graph shown in Figure 1, the initial distribution takes up the following form: 
The evaluation metod of transport system on the basis of semi-Markov model... Metoda oceny systemu transportowego na podstawie semimarkowskiego modelu...

$$
p_{i}(0)=\left\{\begin{array}{lll}
1 & g d y & i=3 \\
0 & g d y & i \neq 3
\end{array}\right.
$$

where

$$
p_{i}(0)=P\{X(0)=i\}, \quad i=1,2, \ldots, 9
$$

whereas the kernel of process $Q(t)$ takes up the form

$$
Q(t)=\left[\begin{array}{ccccccccc}
0 & Q_{12}(t) & Q_{13}(t) & 0 & 0 & 0 & 0 & 0 & 0 \\
0 & 0 & Q_{23}(t) & 0 & 0 & 0 & 0 & 0 & 0 \\
0 & 0 & 0 & Q_{34}(t) & Q_{35}(t) & Q_{36}(t) & 0 & Q_{38}(t) & Q_{39}(t) \\
Q_{41}(t) & 0 & 0 & 0 & 0 & 0 & 0 & 0 & 0 \\
0 & 0 & Q_{53}(t) & 0 & 0 & 0 & 0 & 0 & 0 \\
0 & 0 & Q_{63}(t) & 0 & 0 & 0 & Q_{67}(t) & 0 & 0 \\
0 & 0 & Q_{73}(t) & 0 & 0 & 0 & 0 & 0 & 0 \\
0 & 0 & 0 & 0 & 0 & 0 & 0 & 0 & Q_{89}(t) \\
Q_{91}(t) & 0 & 0 & 0 & 0 & 0 & 0 & 0 & 0
\end{array}\right](3)
$$

where:

$$
\begin{gathered}
Q_{i j}(t)=P\left\{X\left(\tau_{n+1}\right)=j, \tau_{n+1}-\tau_{n} \leq t \mid X\left(\tau_{n}\right)=i\right\} \\
Q_{i j}(t)=p_{i j} \cdot F_{i j}(t) \\
p_{i j}(t)=P\{X(t)=j \mid X(0)=i\}
\end{gathered}
$$

means that the conditional probability of transfer from state $S_{i}$ to state $S_{j}$,

$$
F_{i j}(t)=P\left\{\tau_{n+1}-\tau_{n} \leq t \mid X\left(\tau_{n}\right)=i, X\left(\tau_{n+1}\right)=j\right\}
$$

is a distribution function of random variable signifying period of duration of state $S_{i}$, under the condition that the next state will be state $S_{j}$.

In order to assign the values of limit probabilities $p_{i}{ }^{*}$ of staying in the states of semi-Markov model of transport means operation and maintenance, the following were created: matrix $P$ of the states change probabilities and matrix $\Theta$ of conditional periods of duration of the states in process $X(t)$ : 


$$
\begin{aligned}
P & =\left[\begin{array}{ccccccccc}
0 & p_{12} & p_{13} & 0 & 0 & 0 & 0 & 0 & 0 \\
0 & 0 & 1 & 0 & 0 & 0 & 0 & 0 & 0 \\
0 & 0 & 0 & p_{34} & p_{35} & p_{36} & 0 & p_{38} & p_{39} \\
1 & 0 & 0 & 0 & 0 & 0 & 0 & 0 & 0 \\
0 & 0 & 1 & 0 & 0 & 0 & 0 & 0 & 0 \\
0 & 0 & p_{63} & 0 & 0 & 0 & p_{67} & 0 & 0 \\
0 & 0 & 1 & 0 & 0 & 0 & 0 & 0 & 0 \\
0 & 0 & 0 & 0 & 0 & 0 & 0 & 0 & 1 \\
1 & 0 & 0 & 0 & 0 & 0 & 0 & 0 & 0
\end{array}\right] \\
\Theta & =\left[\begin{array}{ccccccccc}
0 & \bar{\Theta}_{12} & \bar{\Theta}_{13} & 0 & 0 & 0 & 0 & 0 & 0 \\
0 & 0 & \bar{\Theta}_{23} & 0 & 0 & 0 & 0 & 0 & 0 \\
0 & 0 & 0 & \bar{\Theta}_{34} & \bar{\Theta}_{35} & \bar{\Theta}_{36} & 0 & \bar{\Theta}_{38} & \bar{\Theta}_{39} \\
\bar{\Theta}_{41} & 0 & 0 & 0 & 0 & 0 & 0 & 0 & 0 \\
0 & 0 & \bar{\Theta}_{53} & 0 & 0 & 0 & 0 & 0 & 0 \\
0 & 0 & \bar{\Theta}_{63} & 0 & 0 & 0 & \bar{\Theta}_{67} & 0 & 0 \\
0 & 0 & \bar{\Theta}_{73} & 0 & 0 & 0 & 0 & 0 & 0 \\
0 & 0 & 0 & 0 & 0 & 0 & 0 & 0 & \bar{\Theta}_{89} \\
\bar{\Theta}_{91} & 0 & 0 & 0 & 0 & 0 & 0 & 0 & 0
\end{array}\right]
\end{aligned}
$$

Based on the matrix $P$ and on the matrix $\Theta$, average values $\bar{\Theta}_{i}$ of non-conditional duration periods of process states were defined, according to the dependence

$$
\overline{\Theta_{i}}=\sum_{i=1}^{9} p_{i j} \cdot \bar{\Theta}_{i j}, i, j=1,2, \ldots, 9
$$

Therefore, the boundary probability $p_{i}^{*}$ for staining in the states of the semiMarkov processes can be determined on the basis of the boundary statement for the semi-Markov process $[1,2,3]$, in accordance with the following pattern

$$
p_{i}^{*}=\lim _{t \rightarrow \infty} p_{i}(t)=\frac{\pi_{i} \cdot E\left(\Theta_{i}\right)}{\sum_{i \in S} \pi_{i} \cdot E\left(\Theta_{i}\right)}
$$

where probabilities $\pi_{i}, i \in S$ constitute the stationary layout of the implemented Markov's chain in the process which fulfils the system of linear equations

$$
\sum_{i \in S} \pi_{i} \cdot p_{i j}=\pi_{j}, \quad j \in S, \quad \sum_{i \in S} \pi_{i}=1
$$


The evaluation metod of transport system on the basis of semi-Markov model...

Metoda oceny systemu transportowego na podstawie semimarkowskiego modelu...

\section{Availability of transport means defined on the basis of the semi-Markov model of operation and maintenance process}

In order to define availability of technical objects (means of transport) based on the semi-Markovian model of operation and maintenance process, the operational states of the technical object should be divided into availability states $S_{G}$ and non-availability states $S_{N G}$ of the object for the carrying out of the assigned task. In the presented model, the following technical object availability states were enummerated: state $S_{2}$ - awaiting the carrying out of the task at the bus depot parking space, state $S_{3}$ - carrying out of the transport task, state $S_{4}$ - awaiting the carrying out of the task between transport peak hours, state $S_{7}$ - awaiting the start of task realization after technical support rep air. Then the set of availability states:

$$
S_{G}=\left\{S_{2}, S_{3}, S_{4}, S_{7}\right\} .
$$

Availability of a single technical object (mean of transport) defined on the basis of the semi-Markovian model of operation and maintenance process is determined as the sum of limit probabilities $p_{i}$ " of remaining at states belonging to the availability states set

$$
G^{O T}=\sum_{i \in S_{G}} p_{i}^{*}=\frac{\sum_{i \in S_{G}} \pi_{i} \cdot \overline{\Theta_{i}}}{\sum_{i \in S} \pi_{i} \cdot \overline{\Theta_{i}}}
$$

Then, with the use of the MATHEMATICA software, the limit probability $p_{i}{ }^{*}$ of staying in states of semi-Markov process and the availability of transport means were determined

$$
G^{O T}=\frac{p_{12} \cdot\left(p_{34}+p_{38}+p_{39}\right) \cdot \overline{\Theta_{2}}+\overline{\Theta_{3}}+p_{34} \cdot \overline{\Theta_{4}}+p_{36} \cdot p_{67} \cdot \overline{\Theta_{7}}}{\left[\left(p_{34}+p_{38}+p_{39}\right) \cdot\left(\overline{\Theta_{1}}+p_{12} \cdot \overline{\Theta_{2}}\right)\right]+\overline{\Theta_{3}}+p_{34} \cdot \bar{\Theta}_{4}+p_{35} \cdot \overline{\Theta_{5}}+\left[p_{36} \cdot\left(\overline{\Theta_{6}}+p_{67} \cdot \overline{\Theta_{7}}\right)\right]+p_{38} \cdot \overline{\Theta_{8}}+\left(p_{38}+p_{39}\right) \cdot \overline{\Theta_{9}}}
$$

\section{Risk of transport means functioning defined on the basis of the semi-Markov model of operation and maintenance process}

On the basis of definitions contained in Polish Norms, the risk can be defined as:

- product of frequency or probability of a given, dangerous event occurrence and social-economic consequences connected with this event [7].

- product of probability of an undesirable event occurrence and measurements of its effects [8].

Probability of an undesirable or dangerous event occurrence is determined on the basis of data coming from a real operation and maintenance process of technical objects, eg. transport means. Effects of an undesirable or dangerous event can concern both the technical objects (transport means) the man (operator) and the environment. 
The effect of an undesirable or dangerous event can involve financial losses, loss of health or life, reflected most often by costs, range and duration of the discomfort [9]. In this paper, risk of transport means functioning is determined as a product of probability (or sum of probabilities) of its being in an undesirable state (states) of the semi-Markov model of transport means operation and maintenance process and the size of the damage in effect of being in the state (states). The size of the suffered damage is measured by a product of time and unit cost whose quantities are connected with being in the operation and maintenance process undesirable state or states. Then, the dependence describing risk posed by the transport means being in the $i$-th state of the operation and maintenance process model, is given by formula

$$
r_{i}^{O T}=\sum_{i \in S_{N P}} p_{i}^{*} \cdot \bar{\Theta}_{i} \cdot k_{i}^{O T}
$$

where:

$k_{i}^{O T}$ - unit cost born by the transport system, caused by the transport means being in the $i$-th state of the operation and maintenance process,

$S_{N P}$ - subset of states of the operation and maintenance process model considered as undesirable states.

Below, there have been presented measurements of the risk of undesirable events occurrence, connected with transport means failures and the repairs involved:

a) The risk connected with the need to perform a repair of the transport means by the emergency service (without losing a ride and with losing a ride), presented by dependence

$$
r_{E}^{O T}=\sum_{i \in S_{E}} p_{i}^{*} \cdot \bar{\Theta}_{i} \cdot k_{i}^{O T}=p_{5}^{*} \cdot \bar{\Theta}_{5} \cdot k_{5}^{O T}+p_{6}^{*} \cdot \bar{\Theta}_{6} \cdot k_{6}^{O T}
$$

where

$S_{E}$ - subset of the operation and maintenance model process states in which occur costs connected with the transport means repairs by the emergency service;

b) The risk connected with the need to perform a repair of the transport means by the emergency service and in the serviceability assurance subsystem, presented by dependence

$$
r_{R}^{O T}=\sum_{i \in S_{R}} p_{i}^{*} \cdot \bar{\Theta}_{i} \cdot k_{i}^{O T}=p_{5}^{*} \cdot \bar{\Theta}_{5} \cdot k_{5}^{O T}+p_{6}^{*} \cdot \bar{\Theta}_{6} \cdot k_{6}^{O T}+p_{8}^{*} \cdot \bar{\Theta}_{8} \cdot k_{8}^{O T}
$$

where

$S_{R}$ - subset of the operation and maintenance model process states in which occur costs connected with the transport means repairs by the emergency service and in the serviceability assurance subsystem. 
The evaluation metod of transport system on the basis of semi-Markov model... Metoda oceny systemu transportowego na podstawie semimarkowskiego modelu...

Then, with the use of the MATHEMATICA software, the limit probability $p_{i}{ }^{*}$ of staying in states of semi-Markov process and the functioning risk of transport means were determined:

$$
\begin{aligned}
& r_{E}^{O T}=\frac{p_{35} \cdot \overline{\Theta_{5}} \cdot k_{5}^{O T}+p_{36} \cdot \overline{\Theta_{6}} \cdot k_{6}^{O T}}{\left[\left(p_{34}+p_{38}+p_{39}\right) \cdot\left(\overline{\Theta_{1}}+p_{12} \cdot \overline{\Theta_{2}}\right)\right]+\overline{\Theta_{3}}+p_{34} \cdot \overline{\Theta_{4}}+p_{35} \cdot \overline{\Theta_{5}}+\left[p_{36} \cdot\left(\overline{\Theta_{6}}+p_{67} \cdot \overline{\Theta_{7}}\right)\right]+p_{38} \cdot \overline{\Theta_{8}}+\left(p_{38}+p_{39}\right) \cdot \overline{\Theta_{9}}} \\
& r_{R}^{O T}=\frac{p_{35} \cdot \overline{\Theta_{5}} \cdot k_{5}^{O T}+p_{36} \cdot \overline{\Theta_{6}} \cdot k_{6}^{O T}+p_{38} \cdot \overline{\Theta_{8}} \cdot k_{8}^{O T}}{\left(\left(p_{34}+p_{38}+p_{39}\right) \cdot\left(\overline{\Theta_{1}}+p_{12} \cdot \overline{\Theta_{2}}\right)\right]+\overline{\Theta_{3}}+p_{34} \cdot \overline{\Theta_{4}}+p_{35} \cdot \overline{\Theta_{5}}+\left[p_{36} \cdot\left(\overline{\Theta_{6}}+p_{67} \cdot \bar{\Theta}_{7}\right)\right]+p_{38} \cdot \overline{\Theta_{8}}+\left(p_{38}+p_{39}\right) \cdot \overline{\Theta_{9}}}
\end{aligned}
$$

\section{Conclusions}

The presented in the article method is the partial result of carrying out research, which purpose is to develop a comprehensive method of the control process for using the means of transport where semi-Markov processes are used for control. The assessment of the availability and risk connected with technical objects is an issue of complex character and involves determining numerical values of availability and risk and criteria values to be used for deciding whether so determined availability and risk are possible or impossible to be accepted. In further research, there will be carried out experimental tests in a real transport system in order to determine values of the above described availability and risk indexes, and a method for determination of criteria availability and risk assessment values will be developed. Assessment of availability and risk connected with technical objects operation and maintenance can be the point of reference to formulate design requirements concerning of the operated objects (transport means) as well as assumptions concerning design or modernization of the technical means necessary for assurance of the vehicle availability in a given transport system.

\section{References}

[1] Grabski F., Jaźwiński J.: Funkcje o losowych argumentach w zagadnieniach niezawodności, bezpieczeństwa i logistyki. WKiŁ. Warszawa 2009.

[2] Jaźwiński J., Grabski F.: Niektóre problemy modelowania systemów transportowych. Instytut Technologii Eksploatacji. Warszawa-Radom 2003.

[3] Kowalenko I. N., Kuzniecow N. J., Szurienkow W. M.: Procesy stochastyczne. Poradnik. PWN. Warszawa 1989.

[4] Kulkarni V. G.: Modeling and analysis of stochastic systems. Chapman \& Hall. New York 1995.

[5] Migawa K.: Semi-Markov model of the availability of the means of municipal transport system. Zagadnienia Eksploatacji Maszyn, 3(159), vol. 44, Radom 2009. 
[6] Migawa K.: Method for control of technical objects operation process with the use of semi-Markov decision processes. Journal of KONES Powertrain and Transport, vol. 19, no. 4, 2012.

[7] PN-IEC 60300-3-9: Analiza ryzyka w systemach technicznych.

[8] PN-EN 1050: Maszyny. Bezpieczeństwo. Zasady oceny ryzyka.

[9] Szpytko J.: Kształtowanie ryzyka w procesach transportowych. Materiały Konferencji Logitrans, Radom 2009.

[10] Woropay M., Migawa K., Markov model of the operational use process in an autonomous system, Polish Journal of Environmental Studies, Vol. 16, No 4A, 2007.
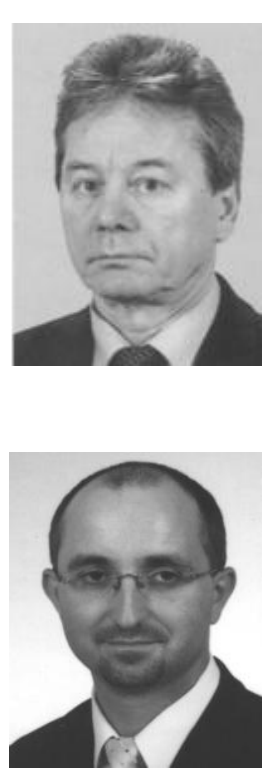

Prof. Maciej Woropay, Ph.D. D.Sc. Eng., professor in the Air Force Institute of Technology in Warsaw. In his research he deals with problems connected with theory of systems, theory of reliability and safety, and maintenance process control in complex biotechnical systems, especially with control of these processes in real transport systems. He is the author and co-author of over 160 scientific papers published in Poland and abroad, as well as textbooks and academic scripts; he has been a promoter of 180 Master's and Bachelor's theses and doctoral theses.

Klaudiusz Migawa, Ph.D. D.Sc. Eng., works at the Faculty of Mechanical Engineering of the UTP University of Science and Technology in Bydgoszcz. In his scientific research he focuses on the problems of modeling and control of processes carried out in complex technological object operation systems. He conducts research on the evaluation of availability, reliability and safety in operation systems of municipal bus transport. 
The evaluation metod of transport system on the basis of semi-Markov model... Metoda oceny systemu transportowego na podstawie semimarkowskiego modelu... 